\title{
Liberal Arts vs. Applied Programming: The Evolution of University Programs in Manitoba
}

\section{DAN SMITH}

University of Manitoba

\section{ABSTRACT}

This investigation seeks to develop data to help understand the direction being taken in university programming in Manitoba over a 35-year period in terms of the perception of alleged growth of the labour market orientation of universities. The impact of the political party in power is examined, as are features of the post-secondary program approval process developed by the intermediary agencies responsible for university matters in Manitoba. Findings suggest that new liberal arts, applied, and mixed programs have increased at roughly the same proportions over the 35-year period in question. Evidence is found, however, of a more recent emphasis on applied programming, supporting claims that university programming is increasingly becoming labour market oriented.

\section{RÉSUMÉ}

Cette étude cherche à utiliser des données recueillies sur une période 35 ans afin de comprendre la direction prise par les universités du Manitoba en terme de perception de la croissance alléguée de l'influence du marché du travail sur les orientations des universités. L'impact du 
parti politique au pouvoir est examiné de même que des dispositifs du processus d'approbation de programmes post-secondaires développés par les agences intermédiaires responsables des programmes de formation dans les universités du Manitoba. Les résultats suggèrent que les nouveaux programmes ont augmenté sensiblement dans les mêmes proportions au cours de la période étudiée. Cependant, au cours des dernières années, il a été trouvé une tendance particulière concernant les programmes appliqués supportant ainsi l'idée que l'offre de formation des universités est de plus en plus orientée vers les besoins du marché du travail.

\section{INTRODUCTION}

The role of the university in preparing people for the labour market has been the subject of enduring controversy. The concept of "labour market orientation" at universities is complex and multi-dimensional, encompassing concerns about research (commercialization, partnerships), private funding (research, infrastructure, autonomy), and job training (teaching, programs, curriculum) (Allen, 1996, 1997; Axelrod, 2002; Lin, Sweet, \& Anisef, 2000; Morgan, 2003; Pocklington \& Tupper, 2002; Smith, 1991). While some of the literature takes the view that the perceived trend of increased labour market orientation of universities is primarily a negative development (Axelrod, 2002; Axelrod, Anisef, \& Lin, 2001; Robertson, McGrane, \& Shaker, 2003; Shapiro, 2003), other work takes a more balanced view (Pocklington \& Tupper, 2002).

While the perceived growth in the labour market orientation at universities has generated a significant amount of literature, little empirical evidence has been presented to substantiate this perception. This study seeks to begin filling this gap by examining university programming so as to develop a better understanding of the trends.

This article examines new programs at universities approved by the Manitoba Universities Grants Commission (UGC) and the Council on Post-Secondary Education (COPSE) between the fiscal years 1967/68 and $2001 / 02$. These two agencies have served (UGC) or continue to serve (COPSE) as intermediaries between the provincial government and the 
universities of Manitoba and Winnipeg, Brandon University, and Collège de Saint-Boniface, monitoring "public expenditures while at the same time providing safeguards for institutional autonomy and promoting flexible institutional responses to local and regional needs" (Mallea, 2002, p. 11). Such agencies are often called "buffer" agencies and will be referred to as such throughout the article.

This article seeks only to identify trends and to leave to others the task of determining whether these trends have a positive or negative influence on universities in Manitoba. Accordingly, the study is limited to answering the following questions:

- Is university programming in Manitoba becoming more oriented towards meeting labour market needs?

- What is the relationship between political philosophies, the buffer agencies, the program approval processes, and the programs approved?

- What does the history of program approval suggest about the steps that could be taken to influence the direction of university programming in Manitoba?

In looking at university programming, the focus is on one of the more commonly understood dimensions of university education - what students are taught. While not discounting other dimensions of labour market orientation in universities, it is likely that teaching and academic programming resonate more with students, parents, governments, and industry which are all turning increasingly to universities to meet their various labour market needs (Morgan, 2003; Sweetman, 2003).

In the following sections, a brief review is presented of the general theoretical and policy context within which new programs are approved. This is followed by a description of the methodological approach, the findings, and the conclusions.

\section{THEORETICAL CONTEXT}

It is commonly held that the elections of Margaret Thatcher and Ronald Reagan in the early 1980 s signaled a movement towards a neo-conservative outlook in the industrialized world (Christian \& Campbell, 1983). 
The growth of neo-conservatism gave renewed vigour to the debate over the instrumental uses of university education, what Shapiro (2003) called the "cult of relevance, which is that the only reason for doing something is because it is immediately useful to something else" (p. 17). The Commission of Inquiry on Canadian University Education (1991), a private commission sponsored by the Association of Universities and Colleges of Canada, stated that "the curriculum, particularly where general (or 'liberal') education is concerned, is the battleground on which is waged a constant struggle between different ideologies and educational philosophies" (pp. 67-68).

Touching on this phenomenon generally, Pratt (1995) wrote:

The traditional model [of university education] was based on 'emancipationist humanism' which trained an elite in ideals that could sustain the emancipation narrative of social development. Lyotard's description of this historical function of education is perhaps more familiar to us in terms of the 'idea of the university' we inherited from John Henry Newman and John Stuart Mill. Education was valued for its own sake, and the professor's role was to enlighten the minds and hearts of those who would interpret truth and justice for their society. But Lyotard's report on the condition of knowledge in the post-modern world discovers a new narrative that has displaced emancipationist humanism. The post-modern narrative for higher education is predicated on the 'performativity of the supposed social system,' and its goal is to teach and create functional skills. Its success is measured by its ability to enhance world competition and to preserve the social cohesion necessary to an efficient economy. (p. 37)

This dichotomy between the more humanist approach to university education and the desire to "create functional skills" expresses a debate in university education that meshes well with the neoconservative agenda that Apple (1995) characterized as commodification and privatization. There is evidence that the trend towards increased instrumental uses of the university, especially in reference to globalization and economic development, exists in Canada (Cutt \& Dobell, 1992) and in Manitoba (Economic Development Board, 1993; University Education Review Commission, 1993).

\section{The Canadian Journal of Higher Education}

Volume XXXV, No. 1, 2005 
Hill (1994) argues that the current political context is simply another chapter in the history of the tension and dialogue "regarding the fundamental purposes and means of higher education" (p. 7). On the one hand, some hold that universities play a key role in the new economy, and that they should focus on meeting the needs of the economy. On the other hand, some staunchly defend the traditional role of the university (Allen, 1998; Sudmant \& Hawkey, 2000). While acknowledging that universities in Canada have always maintained their relevance to the larger society, Pocklington and Tupper (2002) and others (Robertson et al., 2003) imply that as universities move closer to industry, they risk a loss of objectivity, autonomy, integrity, and credibility. It is within this context that new university programs are approved today.

\section{MANITOBA'S POLICY CONTEXT}

Conley (2003) argues that "signals that are sent by formal policies to organizations and across organizational boundaries within a linked system such as education have potentially significant effects on organizational functioning" (p. 2). Thus, Conley would assert, policy matters. This is an important idea in a post-secondary system where policies and processes that affect new university programs are set by a buffer agency. Over the past 35 to 40 years, six different policies have been used to guide the approval of new programs for universities in Manitoba. These policies are described in turn below.

In the first years of the UGC's operations, the Inter-Universities Appraisal Committee, a joint committee of the universities, reviewed new graduate program proposals. Undergraduate program proposals were reviewed by UGC as a whole based on general, but unpublished, guidelines (Universities Grants Commission [UGC], 1971). The period between $1967 / 68$ and $1974 / 75$ will be referred to in the analysis below as "Process 1."

Beginning in 1975/76, a Program Advisory Committee (PAC) was established "as a result of the collapse of the Inter-Universities Appraisal Committee" (UGC, 1975, p. 11). The purpose of the PAC was "to provide 
the expertise required to properly evaluate the new programs" and to provide a recommendation to the UGC (UGC, 1976, p. 4). The eightmember PAC was chaired by a member appointed by the Commission, and was composed of two institutional representatives from each university and one from Collège de Saint-Boniface (UGC, 1975).

Concomitant with PAC's creation was the creation of new guidelines and requirements, "Proposals for New Programs of Study... Policy, Guidelines and Procedures" (UGC, 1977, p. 2) including for the first time a requirement for a "Letter of Intent" outlining the basic elements of a proposed program. If a Letter of Intent was approved by the UGC, a university was authorized to prepare a formal program proposal (UGC, 1976). This process, in place between $1975 / 76$ and 1979/80, will be referred to as "Process 2."

In 1979/80, the PAC was reorganized into a different structure, eliminating institutional representatives from the committee and replacing them with three members of the UGC (UGC, 1980). At the same time, the program approval process was again revised (Process 3), with the PAC taking additional responsibility regarding review and consultations on proposed programs (UGC, 1980).

In 1988/89, another new program approval process was introduced (Process 4). While retaining the essential features, " $[t]$ he new process [focused] attention on the longer-term program development plans of each university, and allowed for a fuller discussion of the relationship between new programs, existing programs, and resource levels" (UGC, 1988, p. 5). This new process provided detailed criteria, including, for the first time, a requirement to discuss labour-market needs. Guidelines pertaining to the preparation of letters of intent required information on "matters such as the level of demand for entry to a program, the need for graduates (where the program is of an applied nature)..." (UGC, 1989, p. 9)

Revisions were again made in 1990/91 (Process 5). This revised process created new deadlines and timelines, but retained criteria related to labour market needs (UGC, 1991a, 1991b). This process remained in effect until the repeal of the Universities Grants Commission Act in 1997 and the establishment of the Council on Post-Secondary Education (COPSE).

The Canadian Journal of Higher Education

Volume XXXV, No. 1, 2005 
In its first year of operation, COPSE (1998) established a PAC composed of agency members only, similar to the PAC structure under the UGC since 1979/80. This lasted until 1999/00 when COPSE eliminated the PAC and began to vet program proposals by the committee of the whole (Mallea, 2002).

In 1998, COPSE developed a program approval process (Process 6) that retained the two-staged approach to program approval that was characteristic of the process under the UGC. This new process was much more specific and detailed regarding labour market needs, requiring, for instance, a "demonstration of market need and market demand for the program for the first 3 to 5 years" (Council on Post-Secondary Education [COPSE], 1998, p. 6).

In summary, since the establishment of the UGC in 1967/68, the program approval process has been composed of two basic parts. The first is the PAC, and both buffer agencies operated with and without PACs. Further, the UGC operated with a PAC that included institutional representatives for a five-year period. The second important structure in program approval was the criteria for approval outlined in the program approval processes, characterized by: (1) a letter/statement of intent stage, and (2) a formal proposal stage.

An inherent part of these requirements is the fact that universities initiate the process, something that is particularly important as it suggests that programming direction is at least in part determined by the universities themselves, based on the extent to which program proposals are designed to reflect the criteria; the direction of programming may be shaped by policies relating to program approval.

The annual reports of the UGC and COPSE provide data regarding rejected proposals between 1975/76 to 1998/99. Accounting for proposals rejected in one year but resubmitted and accepted in another, fully $89.9 \%$ of all new program proposals were approved. In total, 14 program proposals were rejected in the years for which data are available. Two of these programs were rejected in 1992/93 because of pending changes in government strategy in the relevant program area (nursing); four were rejected in 1990/91 because of a lack of resources (communication, 
linguistics, translation, and foreign languages). Specific details for the remaining eight programs (rejected between 1975/76 and 1977/78) are not available.

\section{METHODOLOGY}

Using content analysis, descriptions of approved new programs appearing in the annual reports of the UGC and COPSE are examined. As all new university programs are approved by the buffer agency, all new programs are described in annual reports. Accordingly, the descriptions reflect the beliefs of the agencies regarding the programs.

The content analysis process used in this study sought to examine the underlying meaning of the program descriptions to determine whether or not the buffer agency believed the new program approved to be a liberal arts program, an applied program, or a mixed program. Analysis did not focus on coding for single words or for phrases, but captured a deeper meaning (Babbie, 1989; Colorado State University, 2003). The analytical units used in the analysis are the individual program descriptions, and thus are determined by the description's natural boundaries (Jackson, 2003; Stemler, 2003). Program names are not included in the process of categorization.

Using Mayring's (2001) approach to content analysis, new university programming described in the agencies' annual reports was categorized into "liberal arts," "applied," "mixed," and "excluded" programs. Each of these categories is defined below.

\section{Liberal Arts Programs}

These programs include "academic disciplines, such as languages, history, philosophy, and abstract science, that provide information of general cultural concern" (Billington, 1994, p. 37). Lin et al. (2000) "define liberal education as a pedagogy that provides a broad, balanced, flexible, and human-centred education. Hence, [its] main functions are to advance and disseminate knowledge and to facilitate personal growth and development" (p. 10). Billington (1994) suggests that liberal arts 
can be divided into different program areas: natural sciences, social science, and humanities.

To operationalize this definition, program descriptions are categorized as "liberal arts" if the descriptions indicate that (1) the program is designed to prepare a student for higher levels of education; and/or, (2) liberal education is a stated purpose of the program; and/or, (3) the program is designed to give students a broad-based education in the field in question.

\section{Applied Programs}

Applied programs focus on practical training, such as for a profession (Billington, 1994), or job training (Lin et al., 2000). A program was classified as "applied" if: (1) the program description explicitly stated that the program is designed to meet a labour market need; (2) the description referred to the program as a co-operative education program; (3) the description noted that the program developed skills useful for a specific part of the labour market. An example of an applied program is the Bachelor of Recreation Studies, approved at the University of Manitoba in 1981/82. This program was designed to "meet the demands for professionals to meet the needs caused by recent growth in leisure services" (UGC, 1982, p. 7).

\section{Mixed Programs}

Mixed programs include elements of both liberal arts and applied programs. Accordingly, a program was categorized as mixed if it contained at least one criteria from both the Liberal Arts and Applied program categories. A prototypical example of a mixed program is the Bachelor of Science in Applied Mathematics at the University of Manitoba, approved in 1987/88. This program helps to enable students to undertake "applied mathematical research and development work in business, industry and government. Students graduating from this program should also be well qualified to enter graduate programs" (UGC, 1988, p. 9).

\section{Excluded Programs}

Programs excluded from the analysis were described as being expansions, revisions, or name changes to existing programs; pilot 
studies; process based changes such as adding a distance-based element to an existing program; repeated program descriptions; or descriptions that did not allow for further categorization. In total, excluded programs represented just over one-third (35.4\%) of all programs approved between 1967/68 and 2001/02.

The analysis begins in $1967 / 68$, and follows the UGC until it was replaced by COPSE in 1997/98. The analysis ends in 2001/02, after the first five years of COPSE's operations. The study is thus a census of all new programs approved over the 35-year period in question. Accordingly, the findings are relevant as they represent the entire "population" of new programs introduced in Manitoba's university system since 1967/68. The data show actual trends as to how university programming has changed in Manitoba because $100 \%$ of new programs approved were examined.

\section{FINDINGS}

In the 35-year period examined, a total of 224 new university programs were approved by the UGC/COPSE. Of these, 145 new programs have been included in this analysis, and 79 have been excluded. Of the programs included, roughly the same proportion of programming in each category was approved. A total of 48 new liberal arts programs (33.1\%), 50 applied programs (34.5\%) and 47 mixed programs $(32.4 \%)$ were approved between $1967 / 68$ and 2001/02.

Analysis of the data revealed year-over-year fluctuations in the types and numbers of programs approved. For example, of the 15 new programs approved in 1987/88, 40.0\% were liberal arts, 6.7\% were applied, and 53.3\% were mixed programs, whereas in the next year, five programs were approved with $20.0 \%$ liberal arts, $60.0 \%$ applied, and $20.0 \%$ mixed programs. Ten years later in 1997/98, only two programs were approved, one applied, the other mixed while no new liberal arts programs were approved.

Using two approaches, the history of program approval in Manitoba was broken down into time series to help establish overall trends. Second, three different functional contexts were identified that lend themselves to further investigation of trends in new program approval: the governing 
political party; the buffer agency approving the program; and the processes used to review new programs.

\section{Trends}

Two Equal Time Periods: An overall examination of the 35-year period showed a relatively even distribution of program types. The construction of artificial time periods of equal length helped to assess changes in program types independent of other contexts. The entire 35-year period is examined in two 17-year periods before and after 1984/85. ${ }^{1}$

In the first 17-year period, from $1967 / 68$ to $1983 / 84$, it was more likely that a liberal arts program (39.7\%) would be approved over an applied program $(33.3 \%)$ or a mixed program $(27.0 \%)$. In the 17 years after $1984 / 85$ it was more likely that a mixed program (36.3\%) or an applied program (35.4\%) would be approved over a liberal arts program (28.8\%).

\section{Table 1}

Program Approval in Equal Time Periods

\begin{tabular}{lcccccccc}
\hline $\begin{array}{c}\text { Program } \\
\text { Type }\end{array}$ & \multicolumn{2}{c}{$\begin{array}{c}\text { 17 Years } \\
\text { Before 84/85 }\end{array}$} & \multicolumn{2}{c}{$\begin{array}{c}\text { Barrier Year } \\
\mathbf{8 4 / 8 5}\end{array}$} & \multicolumn{2}{c}{$\begin{array}{c}\text { 17 Years } \\
\text { After 84/85 }\end{array}$} & \multicolumn{2}{c}{ All 35 Years } \\
\hline & $\#$ & \multicolumn{1}{c}{$\%$} & \multicolumn{1}{c}{$\#$} & \multicolumn{1}{c}{$\%$} & \multicolumn{1}{c}{$\#$} & \multicolumn{1}{c}{$\%$} & \multicolumn{1}{c}{$\#$} & \multicolumn{1}{c}{$\%$} \\
\hline Liberal Arts & 24 & 38.7 & 1 & 33.3 & 23 & 28.8 & 48 & 33.1 \\
Applied & 21 & 33.9 & 1 & 33.3 & 28 & 35.0 & 50 & 34.5 \\
Mixed & 17 & 27.4 & 1 & 33.3 & 29 & 36.3 & 47 & 32.4 \\
Total & $\mathbf{6 2}$ & $\mathbf{1 0 0 . 0}$ & $\mathbf{3}$ & $\mathbf{1 0 0 . 0}$ & $\mathbf{8 0}$ & $\mathbf{1 0 0 . 0}$ & $\mathbf{1 4 5}$ & $\mathbf{1 0 0 . 0}$ \\
& & & & & & & & \\
\hline
\end{tabular}

The data in Table 1 show that, in the second time period, the trend was towards applied and mixed programs and away from liberal arts programs. This suggests a stronger emphasis on the labour market in more recent times.

Smaller Time Intervals: By breaking the 35 years into seven intervals of five years each, year-over-year variations are smoothed out. Figure 1 
reveals substantial differences in the percentage of the three types of programming approved throughout the seven different intervals.

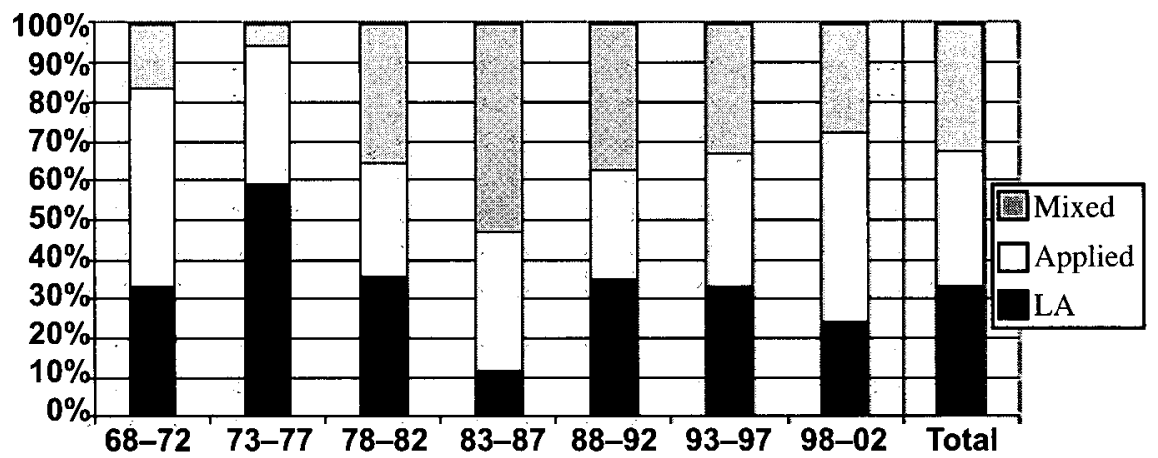

Figure 1: Program Approval in Five Year Intervals

To assist in the interpretation of Figure 1, the variance between the highest and lowest percentage approval is considered for each of the three program types in any of the seven periods. The most variance occurred with liberal arts programming (47.0\%) and mixed programming (47.0\%). In contrast, applied programming approval enjoyed the most stability with a variance rate of only $22.5 \%$.

This analysis suggests volatility in the types of programs approved in Manitoba. By examining the 35-year history of new program approval in two halves, one notes that the number of liberal arts programs approved decreases in proportion to that of applied and mixed programs in the second half of the 35-year period. However, the analysis of smaller time frames reveals neither a smooth nor a linear trend. It is worth noting that Figure 1 shows a steady growth in the approval of applied programming, compared to the other types, beginning with the $88-92$ period. Second, there is relative stability in the approval of applied programming throughout the entire 35-year period.

Overall, this analysis suggests that in more recent years the emphasis in program approval has been away from liberal arts programs. Through examining three functional trends in turn below, these observations are placed into context. 


\section{Governing Political Party}

The literature would suggest that the political environment within which program approval took place was important. Between 1967/68 and 2001/02, two political parties have governed in Manitoba: the Progressive Conservative Party (PC) governed for a total of 18 years, and the New Democratic Party (NDP) for 17 years.

Given the shift towards neo-conservatism identified in the literature, it was expected that new programs approved would be more labour market oriented during periods when the PC Party was in power. An examination of the data suggests that while this was the case, the pattern was weak.

Table 2

Proportion of Program Types Approved by Governing Political Party

\begin{tabular}{lcccc}
\hline \multicolumn{1}{c}{ Program Type } & \multicolumn{2}{c}{ PC } & \multicolumn{2}{c}{ NDP } \\
\hline Liberal Arts & $\#$ & $\%$ & 25 & $\%$ \\
Applied & 23 & 31.1 & 24 & 35.2 \\
Mixed & 26 & 35.1 & 22 & 33.8 \\
Total & 25 & 33.8 & $\mathbf{7 1}$ & $\mathbf{1 0 0 . 0}$ \\
& $\mathbf{7 4}$ & $\mathbf{1 0 0 . 0}$ & & \\
\hline
\end{tabular}

In Manitoba, it would appear neo-conservative influences on university programming, as reflected by political parties, was not as strong a force as suggested by the literature. Indeed, the governing party's influence on the types of programs approved may not be theoretically tenable given the intentional design of the province's university governance system to "buffer" the influence of government through intermediary agencies.

\section{Buffer Agency}

Looking at the data from the perspective of the buffer agency helped to reveal trends in program priorities for each of the two agencies. During the period when the UGC was responsible for university program approval, 
all three program types were approved in about the same proportion, with liberal arts programs slightly more likely to be approved than the others. However, during the COPSE years, an applied program was twice as likely to be approved than was a liberal arts program and nearly twice as likely as a mixed program.

Table 3

Program Approval and Buffer Agencies

\begin{tabular}{lccrc}
\hline \multicolumn{1}{c}{ Program Type } & \multicolumn{2}{c}{ UGC } & \multicolumn{2}{c}{ COPSE } \\
& \multicolumn{1}{c}{$\mathbf{1 9 6 7 / 8 8}-\mathbf{1 9 9 6 / 9 7}$} & \multicolumn{1}{c}{$\mathbf{1 9 9 7 / 9 8 - 2 0 0 1 / 0 2}$} \\
\hline & $\#$ & $\%$ & \multicolumn{1}{c}{$\#$} \\
\hline Liberal Arts & 42 & 35.0 & 6 & 24.0 \\
Applied & 38 & 31.7 & 12 & 48.0 \\
Mixed & 40 & 33.3 & 7 & 28.0 \\
Total & $\mathbf{1 2 0}$ & $\mathbf{1 0 0 . 0}$ & $\mathbf{2 5}$ & $\mathbf{1 0 0 . 0}$ \\
& & & & \\
\hline
\end{tabular}

Looking at the data from the perspective of the buffer agency is informative, but begs the question as to what might be driving these results. Buffer agencies provide not only structure, but also process.

\section{Process}

Both the UGC and COPSE exercised their program approval responsibilities through establishing new program management mechanisms, including program advisory committees and program approval processes.

Program Advisory Committees: Throughout the 35 years under study, PACs were used for all but 11 years. During the years without a PAC, it was more likely that an applied program (47.2\%) would be approved over liberal arts $(38.9 \%)$ or mixed programming (13.9\%). 


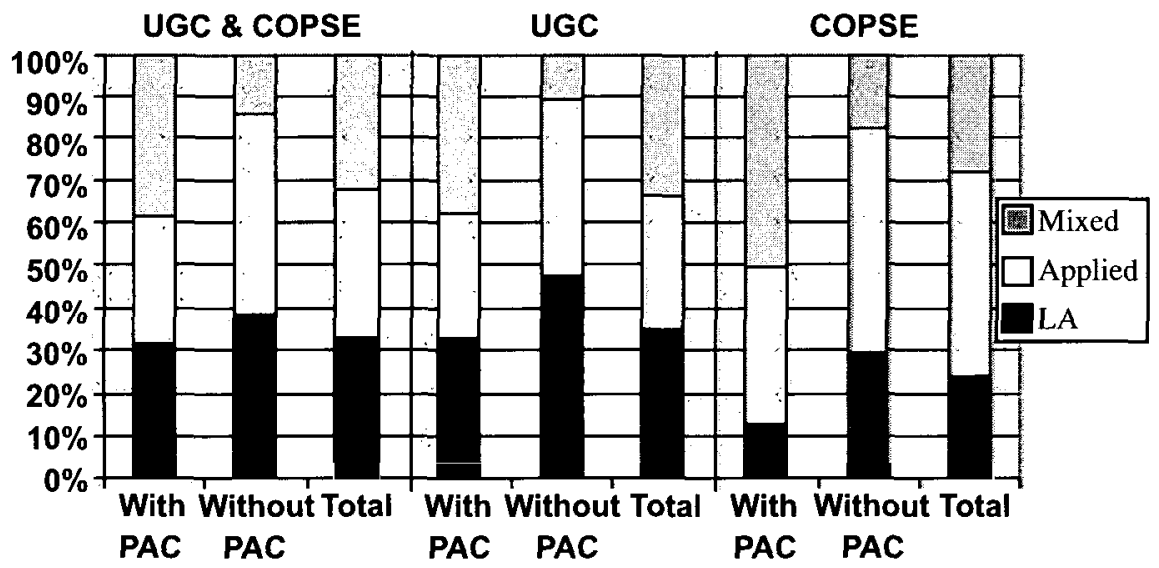

Figure 2: PAC Experience by Buffer Agency

Figure 2 reveals similarities between the various structures. First, for periods when a PAC was in place, more mixed programs and fewer liberal arts programs were approved than when a PAC was not in place. For periods without a PAC, liberal arts and applied programs were approved in greater numbers. In all cases, the UGC was more likely to approve liberal arts programs than was COPSE, and COPSE was more willing to approve applied programs than was the UGC. For both agencies, liberal arts programming fared better without a PAC.

Not shown in Figure 2 are the different PAC arrangements. During the five years when PAC included representatives of each university, liberal arts programs $(35.3 \%)$ were approved at the same rate as were applied (35.3\%), but at a higher rate than mixed programs (29.4\%). During the 19-year timeframe when PAC included only members of the UGC/ COPSE, liberal arts programs $(30.4 \%)$ and applied programs $(29.3 \%)$ were approved in nearly equal proportions, but mixed programs were more heavily favoured $(40.2 \%)$.

This is noteworthy since universities initiate the program approval process, and that throughout the history of the use of buffer agencies in Manitoba, nearly all program proposals received were approved. This further suggests that the specific program approval criteria are important in shaping the programs proposed by the institutions. 
Program Approval by Process

\begin{tabular}{ccccccccc}
\hline & $\begin{array}{c}\text { Process 1 } \\
\text { 67/68-74/75 }\end{array}$ & $\begin{array}{c}\text { Process 2 } \\
\mathbf{7 6 / 7 7 - 7 9 / 8 0}\end{array}$ & $\begin{array}{c}\text { Process 3 } \\
\mathbf{8 0 / 8 1 - 8 7 / 8 8}\end{array}$ & $\begin{array}{c}\text { Process 4 } \\
\mathbf{8 8} / 89-89 / 90\end{array}$ & $\begin{array}{c}\text { Process 5 } \\
\mathbf{9 0 / 9 1 - 9 6 / 9 7}\end{array}$ & $\begin{array}{c}\text { Process 6 } \\
\mathbf{9 7 / 9 8 - 0 1 / 0 2}\end{array}$ & All Processes \\
\hline $\begin{array}{c}\text { LM/ } \\
\text { No LM }\end{array}$ & No LM & No LM & No LM & LM & LM & LM & No LM & LM \\
\hline Liberal Arts & $47.4 \%$ & $35.3 \%$ & $32.0 \%$ & $33.3 \%$ & $31.8 \%$ & $24.0 \%$ & $36.5 \%$ & $28.8 \%$ \\
Applied & $42.1 \%$ & $35.3 \%$ & $22.0 \%$ & $41.7 \%$ & $36.4 \%$ & $48.0 \%$ & $29.4 \%$ & $42.4 \%$ \\
Mixed & $10.5 \%$ & $29.4 \%$ & $46.0 \%$ & $25.0 \%$ & $31.8 \%$ & $28.0 \%$ & $34.1 \%$ & $28.8 \%$
\end{tabular}

* LM refers to some mention of "labour market" need in the program approval process. No LM refers to no mention of labour market need in the process. 
Program Approval Processes: As discussed above, the two buffer agencies used criteria to help guide approval of proposed new programs. Table 4 summarizes program approval findings.

Findings suggest that for those processes not requiring evidence of labour market need ("No LM"), liberal arts programs were favoured, but perhaps more interestingly, there was also a greater balance among the three types of programs approved. However, for those program approval processes that articulated labour market criteria ("LM"), the likelihood of an applied program being approved was much stronger than for either liberal arts or mixed programs. This helps to explain why COPSE appeared to be more focused on applied programs: throughout its short history, it has used a program approval process which has required the most evidence of labour market of all the processes used in the 35-year history of program approval in Manitoba.

\section{DISCUSSION AND CONCLUSION}

The present study acknowledges the continuing debate that exists regarding the uses of university education with respect to preparing people for the labour market. This article has sought evidence to help determine trends in program approval in Manitoba and to understand what may be causing those trends.

Throughout the period studied there has been a fairly even distribution of liberal arts, applied, or mixed programs. However, the number of liberal arts programs approved in the last 17 years of this period has declined, while the number of applied programs approved has increased, revealing a greater labour market orientation for new university programming in more recent times. Interestingly, the number of mixed programs approved was also notable throughout the entire 35-year period, providing support for Pocklington and Tupper's (2002) assertion that universities have always maintained their relevance to society. 
The governing political party appears to have a limited impact, and clear trends could not be discerned from an examination of which buffer agency approved programs. One apparent trend was a relationship between the absence of a PAC and a greater proportion of liberal arts programs being approved, although reasons for this could not be discerned from the data. A second observation was that COPSE was much more oriented towards applied programs than was the UGC, likely a result of the labour market focus of COPSE's program approval process.

The criteria for new program approval appear to be the most important of the three functional contexts examined. Program approval criteria have grown in their complexity and in their focus on labour market need. Indeed, from a brief reference to labour market need in the UGC policy in 1988/89, today "COPSE's procedures for evaluating new programs and courses give considerable weight to occupational criteria" (Mallea, 2002, p. 105). The findings of this study suggest that further investigation into the impact of the criteria for program approval could reveal more details in terms of causation.

An interesting footnote to the above discussion is the absolute number and pace of new program approval during the 35-year time period. The 224 new programs that were added to the university system between $1967 / 68$ and 2001/02 need to be considered within the hundreds of university programs currently offered; the process of transformation is slow.

Another interesting item to note is that, in April 2003 a new form, the "Program Expansion Form," was posted to the COPSE website to address proposals pertaining to the expansion of existing programs, a process formerly captured under the same process as that for new programs (COPSE, 2003). While only 16 of the 224 programs represent expansions of existing programs approved between 1967/68 and 2001/02 (and were thus excluded from the preceding analysis), this new form requires that institutions provide a projection of market demand and market need, and explain how the expanded program corresponds with "the province's economic, social, and cultural priorities" (COPSE, 2003). This suggests that current program approval criteria will continue to foster an applied focus in university programming. 
This article has sought to identify trends in Manitoba with respect to the labour market orientation of university programming and to examine those trends in the light of various functional contexts to develop a better understanding of the direction of that programming. The three research questions posed at the outset have been addressed throughout this study. An analysis of new programming approved between 1967/68 and 2001/02 suggests that, overall, there has been a balance struck between the numbers of liberal arts, applied, and mixed programming at Manitoba universities. However, in more recent years, it appears that applied programming has been the more favoured category, leading to a greater focus on labour market orientation in new university programming.

Three functional contexts were reviewed to help explore the second and third research questions posed in the paper which sought to learn what steps can be taken to influence the direction of university programming in Manitoba. The findings suggest that policy matters; program approval criteria may have a measurable impact on the direction taken in university education in Manitoba. Accordingly, the article also begins a dialogue about the impact buffer agencies have on university systems, providing the modest beginnings of an analysis of post-secondary intermediary agencies in Canadian post-secondary education.

\section{Note}

${ }^{1} 1984 / 85$, the midpoint in the timeframe, is excluded from this analysis, creating two 17-year time periods. By a convenient coincidence, in 1984/85 it was as likely that any of the three program types would be approved. 


\section{References}

Allen, R.C. (1996). The economic benefits of post-secondary training and education in BC: An outcomes assessment (Discussion Paper No. 96-13). Vancouver: University of British Columbia.

Allen, R.C. (1997). The demand and supply of post-secondary education and training in British Columbia (Discussion Paper No. 97-13). Vancouver: University of British Columbia.

Allen, R.C. (1998). The employability of university graduates in the humanities, social sciences, and education: Recent statistical evidence (Discussion Paper No. 98-15). Vancouver: The University of British Columbia.

Apple, M.W. (1995). Cultural capital and official knowledge. In M. Berube \& C. Nelson (Eds.), Higher education under fire: Politics, economics and the crisis of the humanities. (pp. 91-107). New York: Routledge.

Axelrod, P. (2002). Values in conflict: The university, the marketplace and the trials of liberal education. Montreal \& Kingston: McGill-Queen's University Press.

Axelrod, P., Anisef, P., \& Lin, Z. (2001). Against all odds? The enduring value of a liberal education in universities, professions and the labour market. The Canadian Journal of Higher Education, 31(2), 47-78.

Babbie, E. (1989). The practice of social research (5th ed.). Belmont, CA: Wadsworth, Inc.

Billington, D.P. (1994). What is liberal education in a technological era? New Directions for Higher Education, 85, 37-49.

Breneman, D.W. (1994). For whom is liberal education produced? New Directions for Higher Education, 85, 53-59.

Colorado State University. (2003).Writing @ CSU: Writing guidelines: Overview: Content Analysis. Available: http://writing.colostate.edu/ references/research/content.

Conley, D.T. (2003, April). What is the alignment between knowledge and skill for university success and state academic content standards? A paper presented at the Annual Meeting of the American Educational Research Association, Chicago.

Council on Post-Secondary Education. (1998a-2002). Annual report. Winnipeg: Author.

Council on Post-Secondary Education. (1998b). Program approval process: Policies and procedures. Winnipeg: Author. 
Council on Post-Secondary Education. (2003). Program expansion form. Available: www.copse.mb.ca.

Cutt, J., \& Dobell, R. (Eds.). (1992). Public purse, public purpose: Autonomy and accountability in the groves of academe. Montreal: Institute for Research on Public Policy.

Economic Development Board. (1993). Framework for economic growth. Winnipeg: Government of Manitoba.

Hill, B.A. (1994). The nature of liberal education today. New Directions for Higher Education 85, 7-11.

Jackson, W. (2003). Methods: Doing social research (3rd ed.). Toronto: Prentice Hall.

Lin, Z., Sweet, R., \& Anisef, P. (2000 December). Consequences and policy implications for university students who have chosen liberal or vocational education: Labour market outcomes and employability skills. Ottawa: Human Resource Development Canada.

Mallea, J.R. (2002). A review of the Manitoba council on post-secondary education. Erickson, MB: JRM \& Associates.

Manitoba. (1998). The council on post-secondary education act, Chapter 235. Amended 1998, Continuing Consolidation of Statutes of Manitoba, Volume Four.

Manitoba. (2003). Manitoba's action strategy for economic growth. Winnipeg: Manitoba Finance.

Mayring, P. (2001). Qualitative content analysis. Forum: Qualitative Social Research, 1(2), [On-line Journal].

Available: http://www.qualitative-research.net/fqs-texte/2-00/2-00mayring-e.htm

Morgan, G. (2003). Aligning universities for success - Turning out graduates who get good jobs. Policy Options, 24(8), 30-33.

Pocklington, T., \& Tupper, A. (2002). No place to learn: Why universities aren't working. Vancouver: UBC Press.

Pratt, L.R. (1995). Going public: Political discourse and the faculty voice. In M. Berube \& C. Nelson(Eds.). Higher education under fire: Politics, economics and the crisis of the humanities. (pp. 35-51). New York: Routledge.

Robertson, H., McGrane, D., \& Shaker, E. (2003). For cash and future considerations: Ontario's universities and public-private partnerships. Ottawa: Canadian Centre for Policy Alternatives.

Shapiro, B. (2003). Canada's universities: Quantitative success, qualitative concerns. Policy Options, 24(8), 15-17. 
Smith, S.L. (1991). Report of the commission of inquiry on Canadian university education. Ottawa: Association of Universities and Colleges of Canada.

Stemler, S. (2003). An overview of content analysis. Practical Assessment, Research and Evaluation, 7(17).

Available: http://ericae.net/pare/getvn.asp?v=7\&n=17

Sudmant, W., \& Hawkey, C. (2000, October). The flow of post-secondary graduates into the knowledge economy: Evidence from the national graduate survey. A paper presented at the Annual Conference of the Canadian Institutional Research and Planning Association, Saskatoon, Saskatchewan.

Sweetman, A. (2003). Funding flows by two functions-Teaching and research. Policy Options, 24(8), 26-29.

Universities Grants Commission (UGC). (1968-1997). Annual report. Winnipeg: Author.

Universities Grants Commission (UGC). (1991b). Program approval process. Winnipeg: Author.

University Education Review Commission. (1993). Post-secondary education in Manitoba: Doing things differently. Winnipeg: Author. 